\title{
Staff Manuals for Reference Departments In College and University Libraries
}

BY BILLIE BOZONE

Graff manuals have become recognized $\mathcal{N}$ as a generally useful operating device in college and university libraries. Perhaps one of the most important influences in this recognition has been the increasing number of married students whose wives work as sub-professional and clerical assistants from several months to four years. The excessive turnover of full-time staff, plus the ever-changing student staff, has necessitated a crash program in orientation procedures and routines if the department's work is to be carried on consistently and successfully. The adage that a new worker does not earn his salary until after one year on the job cannot be true.

Unfortunately, the staff manual is not something for which the librarian can make out a request form, and receive some days later. The manual must grow out of the staff and conversely, the staff must grow out of the manual. For some staff members, the process of simply getting routines down on paper will make the department's work clearer than would many hours of lectures. Writing the manual also provides an excellent opportunity for the department to evaluate itself-its organization, policies, routines, and standards of service. A department which understands its organization-the "why" and "how"-will work more efflciently than a department which operates on a trial and error basis. In a large system, the manual has an important function in standardizing the work, thereby eliminating error to a large degree. The manual also serves as an interpreter_of the reference department to faculty and staff patrons.

Although much has been written about
Miss Bozone is Assistant Reference Librarian, Mitchell Memorial Library, Mississippi State University.

staff manuals, professional literature on manuals for reference departments per se is meager. Perhaps Mary Barton's milestone at Enoch Pratt has intimidated prospective writers. But that manual, in spite of its excellence, can not be followed too closely for a college or university reference department.

When a reference department concludes that it will compile a staff manual, the first task is the assignment of work. The department head, in consultation with the assistants, should make an outline of all items which will be included.

Primarily, the manual should include all operations, procedures, and routines practiced by the department. It should be concise, easily understood, well-illustrated with forms and records, properly captioned, and written on a level that can be understood by people who have had little or no contact with a reference department. As much as is possible, unexplained library jargon should not be used. PAIS has little meaning to the average college freshman.

The department head should then 'ássign the various items, or sections, to the assistants who are most capable of doing them. After the assignments are clear, the assistants should consult all available sources which have something to do with their particular topic. Library Literature is valuable in locating these sources. Other indexes, such as Readers' Guide Industrial Arts Index-Applied Science 
and Technology Index, Monthly Catalog, and Engineering Index are worth scanning. If possible, other staff manuals should be read. After the staff has saturated itself with material and has made a collection of brief notes, the department head should discuss style and form with them before the actual writing begins. Often, the assistants will have found better methods, more accurate procedures, and more efficient routines than the ones in present use. Perhaps some of the routines now in use are needless and could be discarded completely. At this time, decisions should be made to adopt or reject the newer practices. Consultations with the librarian or director are in order at this point.

When all assistants have finished their assignments, the department head should approve and correct the information before it is typed into the final copy. One last meeting and a final discussion by all the reference department staff members should serve to iron out any wrinkles or inconsistencies which remain.

As many copies of the finished manual as are needed should be typed and put in a loose-leaf notebook. This facilitates corrections and additions. Experience has shown that the best way to compile the manual is to treat it in sections, each section being numbered individually. This greatly facilitates the use of the index, which should be compiled after the finished manual is typed.

Now the reference department has a staff manual. Each new staff memberprofessional, clerical, or student-should be required to read completely the manual during his first week of employment. Thereafter, it should be used as a ready reference work.

It should be emphasized in a manual, and personally, that suggestions for revi. sion are welcomed. The manual should not be taken as a permanent authority, but should be flexible enough to include anything new the department could undertake, without requiring a complete re- writing. The reference department which has not changed its manual in years may well be stagnant and unimaginative.

The following "Table of Contents" from the Reference Department Staff Manual of the Mitchell Memorial Library of Mississippi State University will serve to show the organization of material by one reference departmen ${ }^{1}$ which used the above procedure to compile its manual:

\section{INTRODUCTION}

A. The Refrence Department

Operations and Activities

B. General Regulations
Library Hours
Library Patrons
General Department Policies

C. Student Assistants

Director's Memo

Conditions of Employment

Rates of Pay

General Duties

Student's Time Card

D. The Professional Staff

Qualifications and Educational Requirements

Hours

"Coffee Breaks"

Duties

Closing the Building

E. Locations

Social Sciences and Humanities Reference Room

Physical and Biological Sciences Reference Room (floor plans)

F. Library Classification

Summary

How to Shelve a Book

G. The Stacks

"Closed" Stacks

Locations

H. RULES For THE UsE of Books AND MATERIALS

\section{Routines}

Periodicals

1 Attention should be drawn to the fact that this outline embraces many functions which may fall into other departments in some college and university libraries. However, Mitchell Memorial Library's reference department is subject-divided into two sections, and all bound ment is subject-divided into two sections, and all bound
and current periodicals, manuscripts, government docuand current periodicals, manuscripts, government docu-
ments, etc., are attached to these two reading rooms and are handled by the Reference Department.

(Continued on page 34) 
remain in the documents section, uncataloged for the most part, arranged by UN documents symbols and sales numbers. Because of the incomplete coverage in printed indexes, our library catalogers will continue to catalog and classify Kansas and foreign government publications, but most of these will probably be housed in the documents section. We hope, by taking the foregoing steps, to make the complex mass of government publications easier for faculty and students to get at, especially on the graduate and serious research level where these difficult materials are needed in quantity. We also believe this move will enable the library to service and control documents more efficiently and economically.

\section{Tauber to Australia on Project}

Dr. Maurice F. Tauber, Melvil Dewey professor of library service at Columbia University and editor of $C R L$, will spend March through August in Australia on a Fulbright assignment to assist in a study of the resources of the research libraries of the country. His address will be the Commonwealth National Library, Canberra, Australia. On his way to Australia during February he will visit libraries in Tokyo, Hong Kong, and Singapore. He will return in September by way of Europe. During his absence please address any inquiries regarding articles or other matters relating to $C R L$ to his office at Columbia University and they will be directed to the individuals who will carry on the editing of the magazine while he is away.

\section{Manuals for Reference Departments \\ (Continued from page 20)}

\section{Checking in}

Aids:

List of Foreign Publishing Terms

List of the Months in French, German, Italian, Portugese and Spanish

Roman Numerals

Listing Missing Periodicals

Preparing Periodicals for Binding

Preparing Periodicals for Cardboard Covers

Making New Periodical Subscription Records

Receiving Bound Periodicals from Cataloging

Circulating Periodicals

Reference Techniques

Records:

Attendance Record

Loan Records:

To Faculty and Staff

To other Departments in the Library

To other Colleges and Universities (Interlibrary Loan)

To the Bindery
To Carrells and Studies

Recalling Periodicals or Books Loaned to the University Staff

J. Special Procedures

Mississippi Agricultural Experiment Station and Mississippi Agricultural Extension Service Card Catalog

Bibliography of State Experiment Station Publications

K. Miscellaneous

Elevator

Booklift

Telephone

Supplies

L. INTERLIBRARY LOANS

General Interlibrary Loan Code, 1952

M. Special Divisions

Government Documents

Vertical Files

Mississippi and Rare Books Room including the Cage

Manuscript Collection

APPENDix A. "Guide to the Facilities of Mitchell Memorial Library."

INDEX 